\title{
Antiproliferative effects of cetuximab on triple negative breast cancer cell line MDA-MB-231
}

\author{
Idil ÇETIN ${ }^{1 *}$ (iD) \\ ${ }^{1}$ University of Istanbul, Faculty of Science, Department of Biology, Istanbul, TURKEY
}

\begin{abstract}
In this study, antiproliferative effects of the anti-EGFR monoclonal antibody Cetuximab were evaluated using MDA-MB-231 cell line originated from triple negative breast cancer. As cell kinetic parameters, we evaluated Cell index, mitotic index, labeling index and apoptotic index. For this purpose, $20 \mu \mathrm{M}, 45 \mu \mathrm{M}$ and $60 \mu \mathrm{M}$ Cetuximab concentrations were applied to the cells using the real-time cell analysis system (xCelligence DP) and IC50 values were determined. IC50 concentrations were used for all other parameters. According to experimental results, Cetuximab administration inhibited cell kinetics of MDA-MB-231 cells. xCelligence DP instrument detected IC50 concentrations of Cetuximab for cell line. These values were $45 \mu \mathrm{M}$ for MDA-MB-231 cells. When these IC50 value applied to cells, significant decrease was detected in mitotic index, labelling index and significant increase was detected in apoptotic index for experimental groups. Student's $t$ tests for paired samples were used to assign statistical significance. $\mathrm{p}<0.05$ level of significance was accepted. According to the results obtained, Cetuximab has the potential to slow down the prognosis of the triple negative breast cancer subtype.
\end{abstract}

\section{Article info \\ History:}

Received: 12.06 .2020

Accepted: 01.09.2020

Keywords:

TNBC,

Breast Cancer,

Cetuximab,

MDA-MB-231.

\section{Introduction}

Although cancer seems to be a single disease, it can be described as a disease group formed by the combination of many diseases. Breast cancer, which is the second species of this disease group that causes death in women, has an important place among cancer diseases. Triple-negative breast cancer (TNBC) known as an aggressive cancer type is characterized by its appearance at younger ages, higher average tumor size, high-grade tumors, and sometimes higher rate of node positivity [1]. In addition, this group is known for the occurrence of metastases in the internal organs such as lung and brain, although early peak of relapse and less in bone between the first and third years after diagnosis [2].

One of the member of the class I superfamily of receptor tyrosine kinases (RTKs) is the epidermal growth factor receptor (EGFR). These RTKs include different signaling proteins. All members consist of three regions: 1- Ligand binding site, 2- single membrane-spanning site, 3- site containing a cytoplasmic intracellular tyrosine-kinase. Receptors of this superfamily are expressed in various tissues such as neuronal, epithelial and mesenchymal tissues under normal conditions [3].

EGFR is a tyrosine kinase receptor and is overexpressed in different types of cancer. For instance, breast, ovary, colorectal and head and neck cancer. It plays an important role in the work of mechanisms necessary for tumor formation and progression [4]. EGFR is associated with advanced disease, poor prognosis, and resistance to therapy and therefore EGFR is an ideal candidate for various types of cancer [5].

A monoclonal antibody Cetuximab binds to the extracellular domain of EGFR. In many human cancers, including head and neck and colorectal cancers, EGFR is overexpressed. Binding of EGFR with its endogenous ligand is prevented by this process and this blocks the receptor-dependent transduction pathway, and provides many antitumor agents $[6,7]$.

In this study, it was aimed to evaluate the effects of the anti-EGFR monoclonal antibody Cetuximab on MDAMB-231 cell line originated from triple negative breast cancer at the cellular level by using different cell kinetics parameters. 


\section{Materials and Methods}

\subsection{Cell culture}

The MDA-MB-231 cells used in the experiments were purchased by our research laboratory from American Type Culture Collection (ATTC Manassas, VA, USA). Cells were cultured in DMEM (Invitrogen, Carlsbad, CA, USA) supplemented with $10 \%$ (v/v) fetal bovine serum (FBS; Invitrogen, Carlsbad, CA, USA), 100unit $\mathrm{ml}^{-1}$ penicillin and $100 \mu \mathrm{g} \mathrm{ml}^{-1}$ streptomycin. Cells were maintained at $37{ }^{\circ} \mathrm{C}$ in a atmosphere containing $95 \%$ humidity and $5 \% \mathrm{CO}_{2}$.

\subsection{Preparation of drug concentration}

Application doses of $20 \mu \mathrm{M}, 45 \mu \mathrm{M}$ and $60 \mu \mathrm{M}$ concentrations were prepared by diluting a total of 1 mM Cetuximab (Sigma) stock solution.

\subsection{Cell index (CI)}

For cell index analysis, xCELLigence DP system was used. In experimental process for the impedance background measurement $100 \mu \mathrm{L}$ of appropriate medium was added to each well. Then 5000 cell/well were seeded for MDA-MB-231 cell line. The final volume was $200 \mu \mathrm{L}$. 16 well E-Plates were incubated at $37^{\circ} \mathrm{C}$ with $95 \%$ humidity and $5 \% \quad \mathrm{CO} 2$ and monitored on the RTCA system at 15-minute time intervals for up to 24 hours without treatment and following 72 hours with treatment. The DP unit is wired to an external laptop runing the xCELLigence software (version 1.2.1).

\subsection{Mitotic index (MI)}

For evaluation of MI, cells were planted in 24-well plates. Each well contained $3 \times 10^{4}$ cells for both cell lines. Cells were incubated 24 hrs after cell seeding. Cells were treated with optimum Cetuximab concentration 0-72 hrs. At the end of these experimental period, for fixation, Carnoy fixative was used and the cells were made clear with the Feulgen method and stained with Giemsa. For analysing MI, approximately 3000 cells were counted.

\subsection{Apoptotic index (AI)}

DAPI (6-diamidino-2-phenylindole) was used to determine the apoptotic nucleus. It is a blue fluorescent dye. Cells were cultured in 6-well culture dishes and fixed with methanol: FTS mixture after the experimental process until staining was performed.
Washing was carried out to remove the dye. For washing, PBS was used. A fluorescent microscope was used to identify apoptotic cells.

\subsection{Statistical analysis}

All parameters of cell kinetics (CI, MI, LI, AI) were evaluated according to the controls and each other. Therefore, in order to analyze the results one-way Anova test, Dunnett's test and Student's t-test were used. These statistical analyses were performed using SPSS statistics software (V22.0 IBM, Armonk, NY, USA). In the tests $p<0.05$ level of significance was accepted.

\section{Results}

\subsection{Cell index}

Cell index values obtained by applying Cetuximab to MDA-MB-231 cells at $20 \mu \mathrm{M}, 45 \mu \mathrm{M}$ and $60 \mu \mathrm{M}$ concentrations were compared with the standard curves; while no significant antiproliferative effect can be seen at a concentration of $20 \mu \mathrm{M}$, it is believed that DNA damage occurs at concentrations of $45 \mu \mathrm{M}$ and $60 \mu \mathrm{M}$ (Figure 1). In addition, after $24 \mathrm{~h}$ Cetuximab applying, the $\mathrm{IC}_{50}$ value of MDA-MB-231 cells was determined as $45 \mu \mathrm{M}$ with the $\mathrm{xCelligence} \mathrm{DP} \mathrm{device's}$ own system.

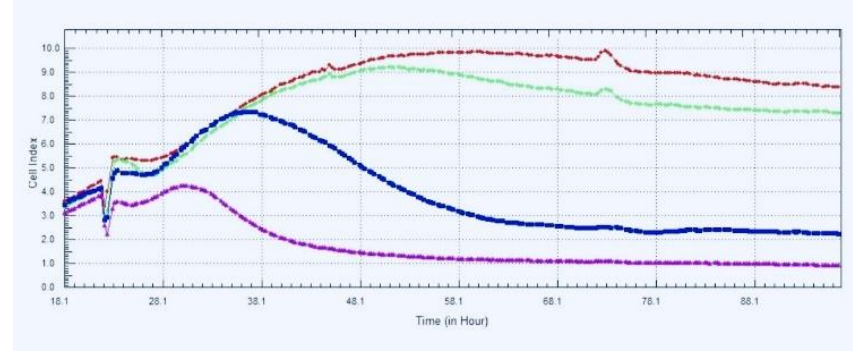

Figure 1: Graph of cell index of MDA-MB-231 cells treated with Cetuximab at concentrations of $20 \mu \mathrm{M}, 45 \mu \mathrm{M}$ and 60 $\mu \mathrm{M}$ (-- Control, -- $20 \mu \mathrm{M},--45 \mu \mathrm{M},--60 \mu \mathrm{M})$.

\subsection{Mitotic Index}

In order to assess the change in mitotic index values by applying Cetuximab on MDA-MB-231 cells; cultured cells were treated at a concentration of $45 \mu \mathrm{M}$ for $24 \mathrm{~h}$, $48 \mathrm{~h}$ and 72 hours. The results showed that this concentration decreased the mitotic index from $4,24 \%$ to $2,76 \%$ at $24 \mathrm{~h}$; from $5,56 \%$ to $1,98 \%$ at $48 \mathrm{~h}$ and $6,18 \%$ to $0,93 \%$ at $72 \mathrm{~h}$ (Figure 2 ). 


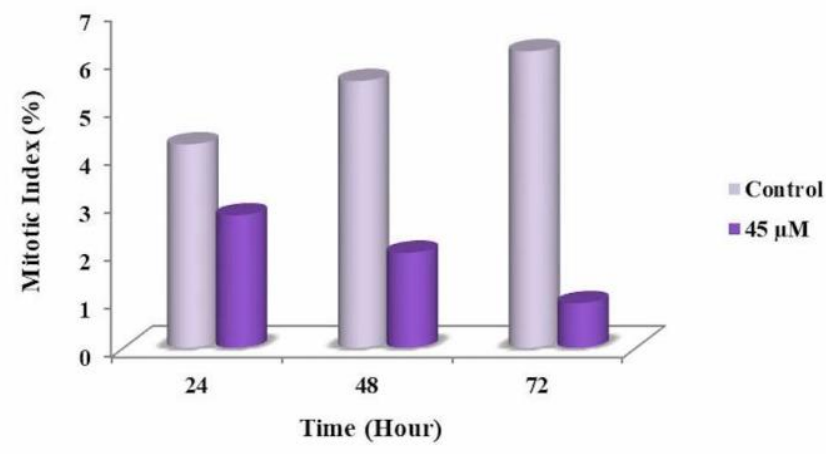

Figure 2: Mitotic index values of MDA-MB-231 cells treated with $45 \mu \mathrm{M}$ Cetuximab for $24-72$ hours ( $\mathrm{p}<0.05$ ).

\subsection{Labelling index}

Labelling index values belonging to MDA-MB-231 cell line after administration of $45 \mu \mathrm{M}$ concentration Cetuximab was shown in Figure 3. Labelling index values decreased from 7,81 to 3,57 at $24 \mathrm{~h}$; from 8,18 to 2,26 at $48 \mathrm{~h}$ and from 8,32 to 1,19 at $72 \mathrm{~h}$ for MDAMB-231 cell line. Labelling index values of MDAMB-231 cells decreased significantly with time as a result of Cetuximab administration. This decrease was statistically significant $(\mathrm{p}<0.05)$.

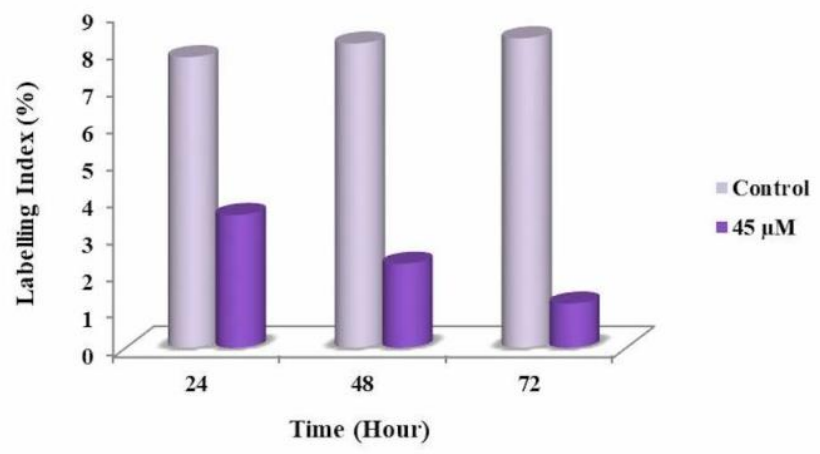

Figure 3: Labelling index values of MDA-MB-231 cells treated with $45 \mu \mathrm{M}$ Cetuximab for $0-72$ hours $(\mathrm{p}<0.05)$.

\subsection{Apoptotic Index}

Administration of $45 \mu \mathrm{M}$ concentration of Cetuximab to MDA-MB-231 cells caused apoptotic cell death. Apoptotic index values increased from 7,23 to 15,26 at $24 \mathrm{~h}$; from 10,62 to 21,22 at $48 \mathrm{~h}$ and from 11,22 to 29,43 at $72 \mathrm{~h}$ for MDA-MB-231 (Figure 4). Apoptotic index values of MDA-MB-231 cells increased significantly with time as a result of Cetuximab administration. This decrease was statistically significant $(\mathrm{p}<0.05)$.

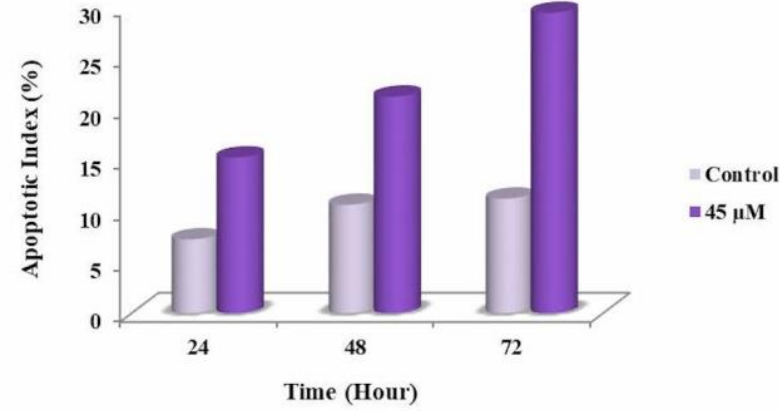

Figure 4: Apoptotic index values of MDA-MB-231 cells treated with $45 \mu \mathrm{M}$ Cetuximab for $0-72$ hours $(\mathrm{p}<0.05)$.

\section{Discussion}

Because of the toxic side effects of traditional drugs used in cancer treatment and the emergence of resistant cells after treatment, cancer treatment is not fully successful and the disease-free survival is reduced [8]. Many studies have shown that triple negative breast cancer has a worse prognosis than hormone receptor positive breast cancers [9- 14]. Current treatment options are limited especially for TNBC among the different types of breast cancers. Therefore discovery and development of novel molecules is very important in terms of treatment options. Among breast cancers, TNBC subtype metastatic progression is characterized by poor prognosis and also. Metastatic progression is one of the poor prognosis indicators of TNBC. In addition, the absence of biomolecules that can be targets for targeted therapies is the main feature of TNBC [15]. Therefore, there are currently no FDAapproved targeted therapies for breast cancer subtypes. At first triple negative breast cancer is very sensitive to chemotherapy, but a lot of triple negative breast cancer patients develop resistance to chemotherapy rapidly, at which point metastatic disease can be quite fatal [16]

In many human malignancies, EGFR is abnormally activated by many mechanisms, such as receptor overexpression, overexpression of receptor ligands, gene amplification [17]. $72 \%$ of patients diagnosed with TNBC have overexpression of EGFR [18-22]. Studies have shown that EGFR mRNA levels are higher in TNBC than luminal A type breast cancer, which is positive for the hormone receptor [23, 24]. Cetuximab activates cellular immunity and antitumor mechanisms while inhibiting the downstream signal of EGFR [25]. In our study the effects of EGFR inhibitor Cetuximab were evaluated MDA-MB-231 cell line which expressed EGFR more.

Experimental findings have led to the several clinical studies' initiation to evaluate the effect of EGFR 
inhibition (EGFRi) on triple negative breast cancer with metastatic potential. In the Phase II study, patients who had advanced breast cancer and who were not previously selected for chemotherapy evaluated EGFR kinase inhibitors [26]. Clinical studies also required the evaluation of the combination of DNA alkylating agent carboplatin with ligand blocking monoclonal antibody Cetuximab in addition to kinase inhibitors [27].

A study by Wang et al using MTT showed that Cetuximab is effective in many cell lines and increases the chemotherapeutic efficacy of other drugs on the cells [28]. In the study with MDA-MB-231 and SUM159 cell lines to evaluate breast cancer stem cells, fluorescence-activated cell sequencer analysis (Aldefluor + or CD44 + and CD24- / low) and mammosphere formation efficacy were measured. In this study, in vitro conditions, cells were treated alone with the combination of Cetuximab or Ixabepilone and Cetuximab. This study using Cetuximab alone or in combination showed that Cetuximab, applied in vitro conditions in breast cancer cells, decreases mammosphere formation efficiency and cancer stem cell population [29].

Brand et al. have demonstrated that after the EGFR expression is deactivated, it remains dependent on EGFR for proliferation of triple negative breast cancer cell types [30]. Liao et al. investigated the efficacy of paclitaxel and cetuximab and conjugated Nanodiamond on the MDA-MB-231 cell line. They found that this combination increased the anticancer effects in this cell line [31]. The study by OliverasFerraros et al. showed that the use of Cetuximab alone inhibits cell viability in MCF10A and MDA-MB-468 cell lines where EGFR is over-expressed compared to other cell lines which EGFR is under-expressed in [32]. In the current study, the use of Cetuximab alone caused an increase in apoptotic index values in triple negative breast cancer cell line MDA-MB-231 which overexpress EGFR.

As a result, in our study; when antiproliferative effects of Cetuximab on MDA-MB-231 cells originated from triple negative breast cancer was evaluated, Cetuximab decreased cell proliferation at an optimum concentration of $45 \mu \mathrm{M}$ concentration for MDA-MB231 cells. It caused a significant decrease in cell index, mitosis phase and cell percentages in synthesis and also caused an increase in apoptotic index.

\section{Acknowledgements}

This work was supported by Scientific Research Project Coordination Unit of Istanbul University. Project No: FBA-2017-24288.

\section{Conflicts of interest}

The authors state that they did not have conflict of interests

\section{References}

[1] Dent R, Trudeau M, Pritchard KI, Hanna WM, Kahn HK, Sawka CA et al. Triple-negative breast cancer: clinical features and patterns of recurrence, Clin Cancer Res, 13 ( 2007), 442934.

[2] Criscitiello C, Azim HA, Schouten PC, Linn SC, Sotiriou C. Understanding the biology of triplenegative breast cancer, Annals of Oncology, 23 (2012), vi13-vi18.

[3] Buettner R, Mora LB, Jove R. Activated STAT signaling in human tumors provides novel molecular targets for therapeutic intervention., Clin Cancer Res, 8 (2002), 945-54.

[4] Hamid O. Emerging treatments in oncology: focus on tyrosine kinase (erbB) receptor inhibitors., J Am Pharm Assoc, 44 (2004), 52-8.

[5] Galizia G, Lieto E, De Vita F, Orditura M, Castellano P, Troiani $\mathrm{T}$ et al. Cetuximab, a chimeric human mouse anti-epidermal growth factor receptor monoclonal antibody, in the treatment of human colorectal cancer., Oncogene, 26 (2007), 3654-60.

[6] Martinelli E, De Palma R, Orditura M, De Vita F, Ciardiello F. Anti-epidermal growth factor receptor monoclonal antibodies in cancer therapy, Clin Exp Immunol, 158 (2009), 1-9.

[7] Koukourakis MI, Tsoutsou PG, Karpouzis A, Tsiarkatsi M, Karapantzos I, Daniilidis V et al. Radiochemotherapy with cetuximab, cisplatin, and amifostine for locally advanced head and neck cancer: a feasibility study, Int $J$ Radiat Oncol Biol Phys, 77 (2010), 9-15.

[8] Muthu M, Cheriyan VT, Rishi AK. CARP-1 / CCAR1: A biphasic regulator of cancer cell growth and apoptosis, Oncotarget, 6 (2015), 6499-6510.

[9] Van de Rijn M, Perou CM, Tibshirani R, Haas P, Kallioniemi O, Kononen $\mathrm{J}$ et al. Expression of cytokeratins 17 and 5 identifies a group of breast carcinomas with poor clinical outcome, Am J Pathol, 161 (2002), 1991-1996. 
[10] Shin BK, Lee Y, Lee JB, Kim HK, Lee JB, Cho SJ et al. Breast carcinomas expressing basal markers have poor clinical outcome regardless of estrogen receptor status, Oncol Rep, 19 (2008), 617-625.

[11] Sørlie T, Perou CM, Tibshirani R, Aas T, Geisler $\mathrm{S}$, Johnsen $\mathrm{H}$ et al. Gene expression patterns of breast carcinomas distinguish tumor subclasses with clinical implications, Proc Natl Acad Sci USA, 98 (2001) 10869-10874.

[12] Sorlie T, Tibshirani R, Parker J, Hastie T, Marron JS, Nobel A et al. Repeated observation of breast tumor subtypes in independent gene expression data sets, Proc Natl Acad Sci USA, 100 (2003), 8418-8423.

[13] Sotiriou C, Neo SY, McShane LM, Korn EL, Long PM, Jazaeri A et al. Breast cancer classification and prognosis based on gene expression profiles from a population-based study, Proc Natl Acad Sci USA, 100 (2003), 10393-10398.

[14] Banerjee S, Reis-Filho JS, Ashley S, Steele D, Ashworth A, Lakhani SR et al. Basal-like breast carcinomas: clinical outcome and response to chemotherapy, J Clin Pathol, 59 (2006), 729735 .

[15] Lehmann BD, Pietenpol JA, Tan AR. Triplenegative breast cancer: molecular subtypes and new targets for therapy, Am. Soc. Clin. Oncol. Educ. Book, 35 (2015) e31-e39.

[16] Uhm JE, Park YH, Yi SY, Cho EY, Choi YL, Lee SJ et al. Treatment outcomes and clinicopathologic characteristics of triplenegative breast cancer patients who received platinum-containing chemotherapy, Int $J$ Cancer, 124 (2009), 1457-1462.

[17] Baselga J, Arteaga CL. Critical update and emerging trends in epidermal growth factor receptor targeting in cancer, J Clin Oncol, 23 (2005) 2445-59.

[18] Viale G, Rotmensz N, Maisonneuve P, Bottiglieri L, Montagna E, Luini A et al. Invasive ductal carcinoma of the breast with the "triple-negative" phenotype: prognostic implications of EGFR immunoreactivity, Breast Cancer Res Treat, 116 (2009), 317-328.

[19] Nielsen TO, Hsu FD, Jensen K, Cheang M, Karaca G, Hu Z et al. Immunohistochemical and clinical characterization of the basal-like subtype of invasive breast carcinoma, Clin Cancer Res, 10 (2004), 5367-5374.

[20] Kim MJ, Ro JY, Ahn SH, Kim HH, Kim SB, Gong G. Clinicopathologic significance of the basal-like subtype of breast cancer: a comparison with hormone receptor and Her2/ neu-overexpressing phenotypes, Hum Pathol, 37 (2006), 1217-1226.

[21] Liu H, Fan Q, Zhang Z, Yu H, Meng F. BasalHER2 phenotype shows poorer survival than basal-like phenotype in hormone receptornegative invasive breast cancers, Hum Pathol, 39 (2008) 167-174.

[22] Shien T, Tashiro T, Omatsu M, Masuda T, Furuta K, Sato N et al. Frequent overexpression of epidermal growth factor receptor (EGFR) in mammary high grade ductal carcinomas with myoepithelial differentiation, J Clin Pathol, 58 (2005) 1299-1304.

[23] El Guerrab A, Bamdad M, Kwiatkowski F, Bignon YJ, Penault-Llorca F, Aubel C. AntiEGFR monoclonal antibodies and EGFR tyrosine kinase inhibitors as combination therapy for triple-negative breast cancer, Oncotarget, 7 (2016) 73618- 73637.

[24] Darbeheshti F, Izadi P, Razavi ANE, Kamali F, Yekaninejad MS, Bazzaz JT. Significance of EGFR mRNA expression in luminal and triple negative breast tumors, International Journal of Cancer Management, 11 (2018), e9763.

[25] Trivedi S, Srivastava RM, Concha-Benavente F, Ferrone S, Garcia-Bates TM, Li J et al. AntiEGFR targeted monoclonal antibody isotype influences antitumor cellular immunity in head and neck cancer patients. Clin Cancer Res, 22 (2016), 5229-37.

[26] Dickler MN, Cobleigh MA, Miller KD, Klein PM, Winer EP. Efficacy and safety of erlotinib in patients with locally advanced or metastatic breast cancer, Breast Cancer Res Treat, 115 (2009) 115-121.

[27] Carey LA, Rugo HS, Marcom PK, Mayer EL, Esteva FJ, Ma CX et al. TBCRC 001: randomized phase II study of cetuximab in combination with carboplatin in stage IV triplenegative breast cancer, J Clin Oncol, 30 (2012) 2615-2623.

[28] Wang F, Chen Y, Huang L, Liu T, Huang Y, Zhao $\mathrm{J}$ et al. Cetuximab enhanced the efficacy of chemotherapeutic agent in ABCB1/Pglycoprotein-overexpressing cancer cells, Oncotarget, 6 (2015, 40850-40865.

[29] Tanei T, Choi DS, Rodriguez AA, Liang DH, Dobrolecki L, Ghosh $\mathrm{M}$ et al. Antitumor activity of Cetuximab in combination with Ixabepilone on triple negative breast cancer stem cells, Breast Cancer Research, 18 (2016) 6.

[30] Brand TM, Iida M, EF Dunn, Luthar N, Kostopoulos KT, Corrigan KL et al. Nuclear Epidermal Growth Factor Receptor Is a Functional Molecular Target in Triple-Negative 
Breast Cancer, Mol Cancer Ther, 13 (2014) 1356-68.

[31] Liao WS, Ho Y, Yu-Wei Lin YW, Raj EN, Liu KK, Chen C. Targeting EGFR of triple-negative breast cancer enhances the therapeutic efficacy of paclitaxel- and cetuximab-conjugated nanodiamond nanocomposite, Acta Biomaterialia, 86 (2019) 395-405.

[32] Oliveras-Ferraros C, Vazquez-Martin A, López-
Bonet E, Martín-Castillo B, Del Barco S, Brunet $\mathrm{J}$ et al. Growth and molecular interactions of the anti-EGFR antibody Cetuximab and the DNA cross-linking agent cisplatin in gefitinibresistant MDA-MB-468 cells: New prospects in the treatment of triple-negative/basal-like breast cancer, International Journal of Oncology, 33 (2008) 1165-1176. 